\title{
Simplification of the tetracyclic SIRT1-selective inhibitor MC2141: Coumarin- and pyrimidine-based SIRT1/2 inhibitors with different selectivity profile
}

\author{
Dante Rotili $^{\mathrm{a}}$, Vincenzo Carafa ${ }^{\mathrm{b}}$, Domenico Tarantino ${ }^{\mathrm{a}}$, Giorgia Botta ${ }^{\mathrm{a}}$, Angela Nebbioso ${ }^{\mathrm{b}}$, \\ Lucia Altucci $^{\mathrm{b}, *}$, Antonello Mai ${ }^{\mathrm{a}, *}$ \\ a Istituto Pasteur-Fondazione Cenci Bolognetti, Dipartimento di Chimica e Tecnologie del Farmaco, Università degli Studi di Roma 'La Sapienza', P.le A. Moro 5, 00185 Roma, Italy \\ ${ }^{\mathrm{b}}$ Dipartimento di Patologia Generale, Seconda Università degli Studi di Napoli, vico L. De Crecchio 7, 80138 Napoli, Italy
}

\section{A R T I C L E I N F O}

\section{Article history:}

Received 15 November 2010

Revised 22 December 2010

Accepted 13 January 2011

Available online 19 January 2011

\section{Keywords:}

Sirtuins

Selective inhibition

Apoptosis

Cytodifferentiation

\begin{abstract}
A B S T R A C T
In this report we describe the synthesis and biological characterization of two series of sirtuins' inhibitors (SIRTi), designed as simplification products of the previously reported SIRT1-selective inhibitor MC2141 (4). In the first series (5a-t) we report a number of 2-substituted-1,2-dihydrobenzo[f]chromen-3-ones with a marked selectivity for the inhibition of SIRT2 over SIRT1. Some of such derivatives showed also high pro-apoptotic (5i and $\mathbf{5 1}$ ) and/or cytodifferentiating (5d, 5i, and $\mathbf{5 o}$ ) properties in a human leukemia cell line (U937). The second group of SIRTi $(\mathbf{6 a}-\mathbf{q})$ is characterized by some analogues of cambinol (3), a well known SIRTi active against the Burkitt lymphoma. Such compounds, differently from the unselective prototype, are endowed with a selective inhibition of SIRT1 over SIRT2, and, in some cases $(\mathbf{6 j}$, $6 \mathbf{k}$, and $\mathbf{6 q )}$, are more efficient than $\mathbf{3}$ to induce apoptosis in U937 cells.
\end{abstract}

(c) 2011 Elsevier Ltd. All rights reserved.

\section{Introduction}

Class III histone deacetylases (HDACs), also called sirtuins (SIRTs) from their founding member, the Sir2 (silent information regulator 2) protein of Saccharomyces cerevisiae, are seven enzymes in humans (SIRT1-7) which have $\mathrm{NAD}^{+}$as a co-substrate for their catalytic activity, show no homology with the other classes of HDACs, and are sensible to specific inhibitors. ${ }^{1}$ SIRTs catalyze the removal of the acetyl group from the lysine residues of their substrates, coupling this event with the hydrolysis of $\mathrm{NAD}^{+}$to generate nicotinamide, deacetylated protein, and $O$-acetyl-ADP-ribose. ${ }^{1,2}$ The ADP-ribosyl transferase activity of sirtuins was long time considered a low efficiency side-reaction due to the partial uncoupling of intrinsic deacetylation and acetate transfer to ADP-ribose. Recently, however, mono-ADP-ribosyl transferase (mART) activity has been found to be the main enzymatic activity of at least two human sirtuins, SIRT4 and SIRT6, whereas SIRT2 and SIRT3 display

Abbreviations: BCL6, B-cell lymphoma 6; FACS, fluorescence activated cell sorting; FOXO, forkhead box class $\mathrm{O}$; $\mathrm{NAD}^{+}$, nicotinamide adenine dinucleotide; $N F-\kappa B$, nuclear factor $-\kappa B$; PGC- $1 \alpha$, peroxisome proliferator-activated receptor $\gamma$ coactivator $1 \alpha$; SIRT, silent information regulator 2 type enzyme.

* Corresponding authors. Tel.: +39 081 5667569; fax: +39 081450169 (L.A.); tel +3906 49913392; fax: +3906 49693268 (A.M.).

E-mail addresses: lucia.altucci@unina2.it (L. Altucci), antonello.mai@uniroma1.it (A. Mai). both deacetylase and mART activities. ${ }^{3}$ Moreover, to date, no robust enzymatic activity has been found for SIRT7 as yet.

Like class I, II, IV HDACs, besides histones sirtuins deacetylate and/or ADP-ribosylate many other important proteins, including transcription factors (FOXO1, NF- $\kappa \mathrm{B}, \mathrm{MEF} 2, \mathrm{HOXA10,}$ PGC1- $\alpha$, etc.), enzymes (AceCS1/2, GDH, p300), nuclear receptors (androgen receptor), and other regulatory (HIV Tat) and structural ( $\alpha$-tubulin) proteins, so modulating their own activities. ${ }^{1-4}$ These evidences can explain the multiple biological functions of sirtuins, that range from repression of gene expression to regulation of cellular cytodifferentiating and/or apoptotic processes, from control of energetic metabolism to aging. ${ }^{1-4}$ In yeast, Sir2 is critical for transcriptional silencing at three specific loci: the telomeres, ribosomal DNA, and the silent mating type loci. ${ }^{5,6}$ Sir2 and its homologues have gained considerable attention for their ability to mimic the diet known as caloric restriction, which extends lifespan in a variety of organisms, including yeast, ${ }^{7}$ Caenorhabditis elegans, ${ }^{8}$ rodents, ${ }^{9}$ and probably primates. ${ }^{10}$ Since their catalytic activity depends on the intracellular levels of the co-substrate $\mathrm{NAD}^{+}$and of the vitamin nicotinamide, that at physiological conditions exerts the classical non-competitive product inhibition, sirtuins have also been proposed as sensors of the cell metabolic state. ${ }^{1-4}$ Moreover, since these enzymes in humans regulate cell survival under stress conditions as well as neuro/cardio protection, stimulate insulin secretion and lipolysis, and inhibit adipogenesis, sirtuins' activators (such as resveratrol) have been proposed for the treatment 
of some age-related diseases (type 2 diabetes, neurodegeneration, heart failure, etc.) and specific metabolic disorders (obesity, atherosclerosis, etc.). ${ }^{11,12}$ Since sirtuins have been found upregulated in many tumor types (SIRT1/3/7), are able to inactivate at transcriptional and posttranslational level some tumor suppressor proteins ( $\mathrm{p} 53, \mathrm{p} 73$, etc.) and to activate the oncoprotein BCL6 (SIRT1), exert anti-apoptotic and anti-differentiation activities (SIRT1) through deacetylation of specific transcription factors (E2F1, FOXO3a, Ku70, etc.), and regulate DNA repair (SIRT1/6), cell-cycle progression, and chromosomal stability (SIRT1/2), the inhibitors of such proteins (SIRT1 in particular) have been proposed as potential anti-cancer agents. ${ }^{13-15}$ Recently, a SIRT2 specific inhibitor (AGK-2) has also been proposed as a useful agent for protection against $\alpha$-synuclein-induced toxicity in different models of Parkinson's disease. ${ }^{16}$

When compared with the great number of class I/II/IV HDAC inhibitors reported so far, a small number of sirtuin inhibitors (SIRTi) have been described, but this field is in constant expansion (Fig. 1). ${ }^{17}$ By a medicinal chemist point of view, the first SIRTi can roughly be grouped into $\mathrm{NAD}^{+}$derivatives (nicotinamide,
carba-NAD ${ }^{+}, \mathrm{NADH}$ ), coumarin derivatives (dihydrocoumarin, A3, splitomicin (1), HR-73 (2)), and 2-hydroxynaphthaldehyde derivatives (2-OH-naphthaldehyde, sirtinol, para-sirtinol, M15, cambinol (3), salermide). ${ }^{18}$ Recently, some compounds bearing different scaffolds (JFD00244, TRIPOS 360702, Ro-31-8220) have been identified as SIRT inhibitors through virtual screening methods, ${ }^{19-21}$ and the suramin derivative NF- $675^{22}$ as well as the tetrahydrocarbazole EX-527 $7^{23}$ displayed high and selective SIRT1 inhibitory activity. A number of SIRTi from natural sources has been also reported, such as (+)-guttiferone $G$ and its structural analogues hyperforin and artisoforin, ${ }^{24}$ endowed with antiproliferative activity on human umbilical vein endothelial cells (HUVEC), the SIRT2 inhibitor tanikolide dimer, ${ }^{25}$ and the SIRT1 inhibitor amurensin $\mathrm{G}^{26}$ able to restore doxorubicin responsiveness in doxorubicinresistant breast cancer MCF-7/ADR cells. Cambinol (3), active at micromolar level against both SIRT1 and SIRT2, when tested on BCL6-expressing Burkitt lymphoma cells as well as on Burkitt lymphoma mouse xenografts, was able to induce apoptosis with concomitant hyperacetylation of BCL6 and p53. Moreover, it was well tolerated and inhibited the tumor growth in the animal<smiles>O=C1CCc2c(ccc3ccccc23)O1</smiles>

splitomicin (1)<smiles>O=C1Oc2ccc3cc(Br)ccc3c2CC1c1ccccc1</smiles>

HR-73 (2)<smiles>CC(NC(=O)c1ccccc1/N=C/c1c(O)ccc2ccccc12)c1ccccc1</smiles><smiles>O=c1[nH]c(=S)[nH]c(-c2ccccc2)c1Cc1c(O)ccc2ccccc12</smiles>

cambinol (3)<smiles>CC(C(=O)Nc1cccc(/N=C/c2c(O)ccc3ccccc23)c1)c1ccccc1</smiles><smiles>Nc1cc(C(=O)Nc2cccc(C(=O)Nc3ccc(S(=O)(=O)O[Na])c4cc(S(=O)(=O)O[Na])cc(S(=O)(=O)O[Na])c34)c2)cc(C(=O)Nc2ccc(S(=O)(=O)O[Na])c3cc(S(=O)(=O)O[Na])cc(S(=O)(=O)O[Na])c23)c1</smiles><smiles>[R7][R6]#[R]</smiles>

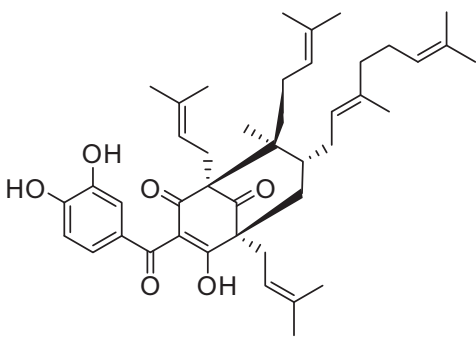

(+)-guttiferone G<smiles>CCCCCC(=O)OC(C)(CC)CO</smiles>

tanikolide dimer

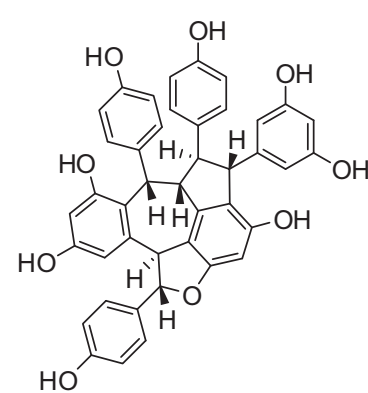

amurensin $\mathrm{G}$<smiles>O=c1nc2oc3ccc4ccccc4c3cc-2c(=O)n1-c1ccccc1</smiles>

Figure 1. Chemical structures of known SIRTi. 


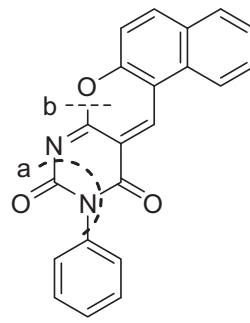

MC2141 (4)
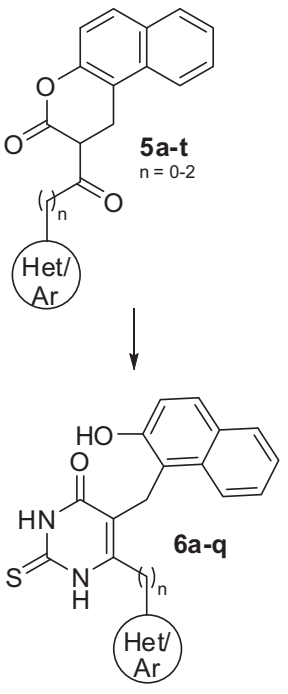

Figure 2. MC2141 (4) structural simplification plan.

model. ${ }^{27}$ Recently, tenovins have been reported to induce hyperacetylation of p53, to inhibit the deacetylating activities of SIRT1 and SIRT2, and to decrease tumor growth in vivo as single agents. ${ }^{28}$ Very recently, also the SIRT1/2 inhibitor salermide, developed by our research group, showed very promising cancer-specific proapoptotic properties in a panel of tumor cell lines. ${ }^{29}$

Pursuing our efforts for identifying epigenetic-disorder-modifying agents ${ }^{30-35}$ and, in particular, sirtuins modulators, ${ }^{36-38}$ we recently identified the 10-phenyl-7-oxa-8,10-diazabenzo[a]anthracene-9,11-dione (MC2141, 4) as the prototype of a novel series of tri- and tetracyclic pyrimidinediones (benzodeazaoxaflavins, BDF4s) as SIRTi endowed with high and selective SIRT1 inhibition and a promising antiproliferative activity in human cancer cell lines. ${ }^{39}$ Here we report a systematic med-chem structural simplification approach on $\mathbf{4}$ aimed to improve its solubility and drug-like properties (Fig. 2).

Firstly, we simplified the tetracyclic scaffold of the BDF4 prototype 4 by removal of the pyrimidinedione portion, and prepared of a series of differently substituted 2-(hetero)aroyl or 2-arylalkanoyl-1,2-dihydrobenzo[f]chromen-3-ones (5a-t), which are also structurally related to other benzochromene-containing
SIRTi such as splitomicin ${ }^{40}(\mathbf{1})$ and HR-73 ${ }^{41}$ (2). Then, we opened and reduced the central pyran ring of the tetracyclic core of $\mathbf{4}$ producing a series of variously substituted 6-(hetero)aryl or 6-arylalkyl substituted 5-(2-hydroxynaphthalen-1-ylmethyl)-2thioxo-2,3-dihydro-1H-pyrimidin-4-ones (6a-q). Such derivatives, easily prepared from the proper benzo[f]chromenones $\mathbf{5}$, can be also considered analogues of cambinol (3) (Fig. 2). All the synthesized compounds ( 5 and $\mathbf{6}$ ) were tested for their ability to inhibit the enzymatic activity of human recombinant SIRT1 and SIRT2 and for their effects on human leukemia U937 cells.

\section{Results and discussion}

\subsection{Chemistry}

The 2-substituted-3H-benzo[f]chromen-3-ones (8a-t) were prepared by Knoevenagel condensation between the commercially available 2-hydroxy-1-naphthaldheyde and the proper $\beta$-ketoesters $(\mathbf{7 a - t}),{ }^{38,39,42}$ prepared by a standard previously reported procedure. ${ }^{43}$ The 2-(hetero)aroyl or 2-arylalkanoyl-1,2-dihydrobenzo[f]chromen-3-ones (5a-t) were then obtained by reduction of the intermediates 8a-t with sodium borohydride in dry pyridine (Scheme 1). ${ }^{38,39,42}$ The 6-substituted-5-(2-hydroxynaphthalen1-ylmethyl)-2-thioxo-2,3-dihydro-1 $H$-pyrimidin-4-ones $\mathbf{6 a - q}$ were finally synthesized upon treatment of the 1,2-dihydrobenzo[f]chromen-3-ones (5a-n, p, r, s) with thiourea in dry ethanol in the presence of sodium ethoxide (Scheme 1). ${ }^{42,43}$

The reference compounds splitomicin (1), HR-73 (2), and cambinol (3) were prepared following the procedures reported in the literature. ${ }^{40-42}$ Chemical and physical data of the novel final compounds $\mathbf{5 g - i}, \mathbf{k - s}$ and $\mathbf{6 a}, \mathbf{g}-\mathbf{q}$ are listed in Table 1 . Chemical and physical properties of the already reported final compounds $\mathbf{5 a - f}$, $\mathbf{j}, \mathbf{t}$ and $\mathbf{6 b - f}$ are in agreement with the literature data. ${ }^{39,42}$ Chemical and physical properties of the novel intermediates $\mathbf{8 g} \mathbf{- i}$, $\mathbf{k}, \mathbf{m}-\mathbf{s}$ are reported in Supplementary data, while chemical and physical data of the known intermediates $8 \mathbf{a}-\mathbf{f}, \mathbf{j}, \mathbf{1}, \mathbf{t}$ are in agreement with the literature. ${ }^{39,42,44}$

\subsection{Sirtuin inhibitory activity}

The two series of the 4-simplified derivatives, compounds $\mathbf{5 a - t}$ and $\mathbf{6 a - q}$, were tested at $50 \mu \mathrm{M}$ against hrSIRT1 and hrSIRT2 (Table 2). Compounds $\mathbf{3}$ and $\mathbf{4}$ were included in the tests for

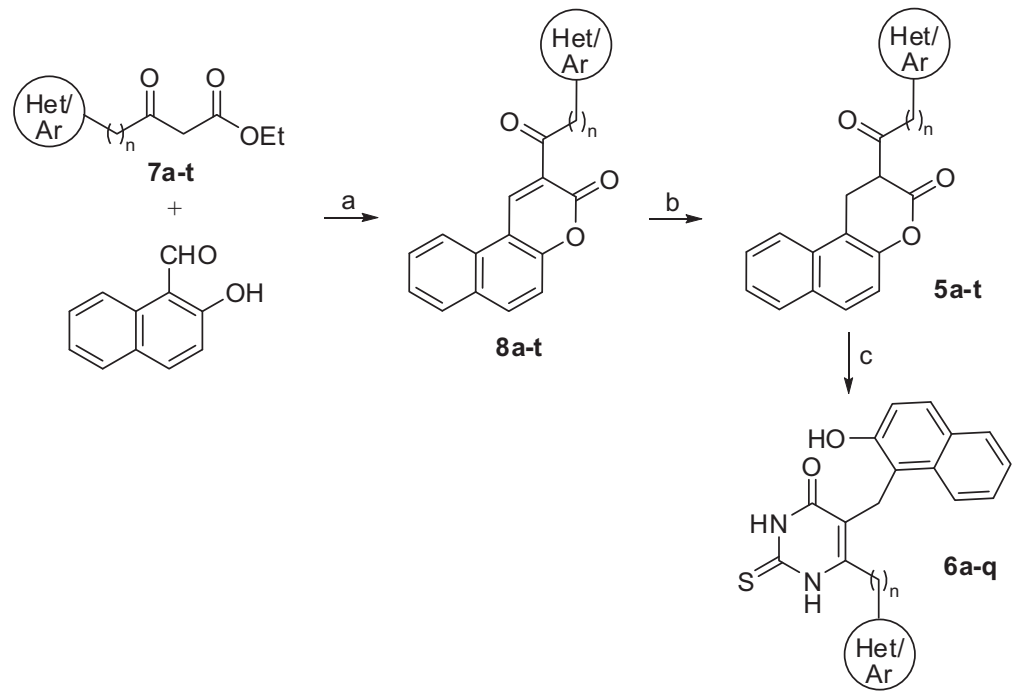

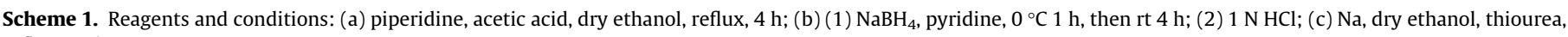
reflux, $18 \mathrm{~h}$. 
Table 1

Chemical and physical data of compounds $5 \mathbf{g}-\mathbf{i}, \mathbf{k}-\mathbf{s}$ and $\mathbf{6 a}, \mathbf{g}-\mathbf{q}$<smiles>[R]C(=O)C1Cc2c(ccc3ccccc23)OC1=O</smiles><smiles>[R]c1[nH]c(=S)[nH]c(=O)c1Cc1c(O)ccc2ccccc12</smiles>

6a,g-q

\begin{tabular}{|c|c|c|c|c|}
\hline Compd & $\mathrm{R}$ & $\operatorname{Mp}\left({ }^{\circ} \mathrm{C}\right)$ & Recryst. system ${ }^{\mathrm{a}}$ & Yield (\%) \\
\hline $5 g$ & 1-Naphthyl & $166-168$ & A & 83 \\
\hline $5 h$ & 2-Naphthyl & $186-188$ & $\mathrm{~B}$ & 84 \\
\hline $5 \mathbf{i}$ & 4'-Biphenyl & $202-204$ & A & 78 \\
\hline $5 \mathbf{k}$ & 3-Furanyl & $239-240$ & C & 79 \\
\hline 51 & 2-Thienyl & $153-154$ & $\mathrm{C}$ & 81 \\
\hline $5 \mathrm{~m}$ & 3-Thienyl & $170-171$ & $\mathrm{C}$ & 75 \\
\hline $5 n$ & $N$-Methyl-1H-2-pyrrolyl & $196-198$ & C & 76 \\
\hline 50 & 4-Pyridyl & $158-160$ & $\mathrm{C}$ & 43 \\
\hline $5 p$ & 2-Benzo $[b]$ thienyl & $208-209$ & $\mathrm{C}$ & 73 \\
\hline $5 q$ & 2-Benzo[b]furanyl & 204-206 & C & 78 \\
\hline $5 r$ & $\mathrm{PhCH}_{2}$ & $128-130$ & A & 80 \\
\hline $5 s$ & $\mathrm{PhCH}_{2} \mathrm{CH}_{2}$ & $70-71$ & $\mathrm{D}$ & 55 \\
\hline $6 \mathbf{a}$ & $2-\mathrm{Cl}-\mathrm{Ph}$ & $>250$ & $\mathrm{E}$ & 14 \\
\hline $6 \mathrm{~g}$ & 1-Naphthyl & $209-212$ & $\mathrm{E}$ & 67 \\
\hline $6 h$ & 2-Naphthyl & $259-262$ & $\mathrm{~F}$ & 33 \\
\hline $6 \mathbf{i}$ & 4'-Biphenyl & $>250$ & $\mathrm{E}$ & 20 \\
\hline $6 \mathbf{j}$ & 2-Furanyl & $245-248$ & $\mathrm{E}$ & 36 \\
\hline $6 \mathbf{k}$ & 3-Furanyl & $>250$ & $\mathrm{E}$ & 52 \\
\hline 61 & 2-Thienyl & $>250$ & $\mathrm{~F}$ & 40 \\
\hline $6 \mathrm{~m}$ & 3-Thienyl & $>250$ & $\mathrm{~F}$ & 36 \\
\hline $6 n$ & $N$-Methyl-1H-2-pyrrolyl & $234-237$ & $\mathrm{~F}$ & 35 \\
\hline 60 & 2-Benzo $[b]$ thienyl & $>250$ & $\mathrm{E}$ & 21 \\
\hline $6 p$ & $\mathrm{PhCH}_{2}$ & $167-171$ & $\mathrm{E}$ & 42 \\
\hline $6 q$ & $\mathrm{PhCH}_{2} \mathrm{CH}_{2}$ & $244-247$ & $\mathrm{E}$ & 29 \\
\hline
\end{tabular}

a A: ethyl acetate; B: ethyl acetate/tetrahydrofuran; C: acetonitrile; D: petroleum ether; E: chloroform; F: chloroform/methanol.

comparison. In the first series $(\mathbf{5 a}-\mathbf{t})$, the introduction of chlorine or methyl substituent at the ortho, meta or para position of the benzene ring of the 2-benzoyl-1,2-dihydrobenzo[f]chromen-3-one (5t) conferred a significant selectivity in the inhibition of SIRT2 $>>85 \%$ of inhibition at $50 \mu \mathrm{M})$ over SIRT1 $(11-28 \%$ of inhibition at $50 \mu \mathrm{M})$. The same degree of selectivity was obtained through substitution of the entire phenyl ring with bulkier aromatic groups (5g-i), with furanyl (5j, k) and 3-thienyl (5m) rings, and with the more flexible benzyl (5r) and phenethyl (5s) moieties. Moderate SIRT2 selectivity was displayed by the $N$-methyl-1H-2-pyrrolyl derivative 5n and the 4-pyridyl compound 5o. No SIRT2 selective inhibition was observed with the 2-thienyl derivative (51) and with the heteroaromatic bicyclic compounds $\mathbf{5 p}$ and $\mathbf{5 q}$ that, similarly to the prototype $\mathbf{5 t}$, showed moderate inhibitory activities against both the tested sirtuins. IC $_{50}$ values against SIRT2 and/or SIRT1 were determined for selected $\mathbf{5}$ derivatives (Table 3 ). On the basis of these enzymatic assays, we can conclude that the removal of the pyrimidine portion of the tetracyclic scaffold of $\mathbf{4}$ leads to simplified derivatives $(\mathbf{5 a} \mathbf{a}-\mathbf{t})$ with a reduced inhibitory activity against SIRT1, while most of the substitutions at the 2 position of the 1,2-dihydrobenzo[f]chromen-3-one tricyclic system lead to selective SIRT2 inhibitors.

Compounds 6a-q, when compared with the lead structure $\mathbf{3}$, showed in general higher SIRT1 and equal or lower SIRT2 inhibitory activity. The introduction of substituents (2-, 3-, or 4-chloro; $2-, 3-$, or 4-methyl; 4-phenyl) at the C-6 phenyl ring as well as the replacement of the C- 6 phenyl with either naphthyl or mono/ bicyclic heteroaromatic rings gave only modulator effects on the inhibiting action of the derivatives. Also the increase of the distance between the pyrimidine C-6 position and the phenyl ring with one or two methylene groups (compounds $\mathbf{6 p}, \mathbf{q}$ ) led to the same results. Basically, $\mathbf{6 a - q}$ showed high inhibitory potency and
Table 2

Inhibition of SIRT1/2 by the compounds $\mathbf{5 a}-\mathbf{t}$ and $\mathbf{6 a}-\mathbf{q}^{\mathrm{a}}$

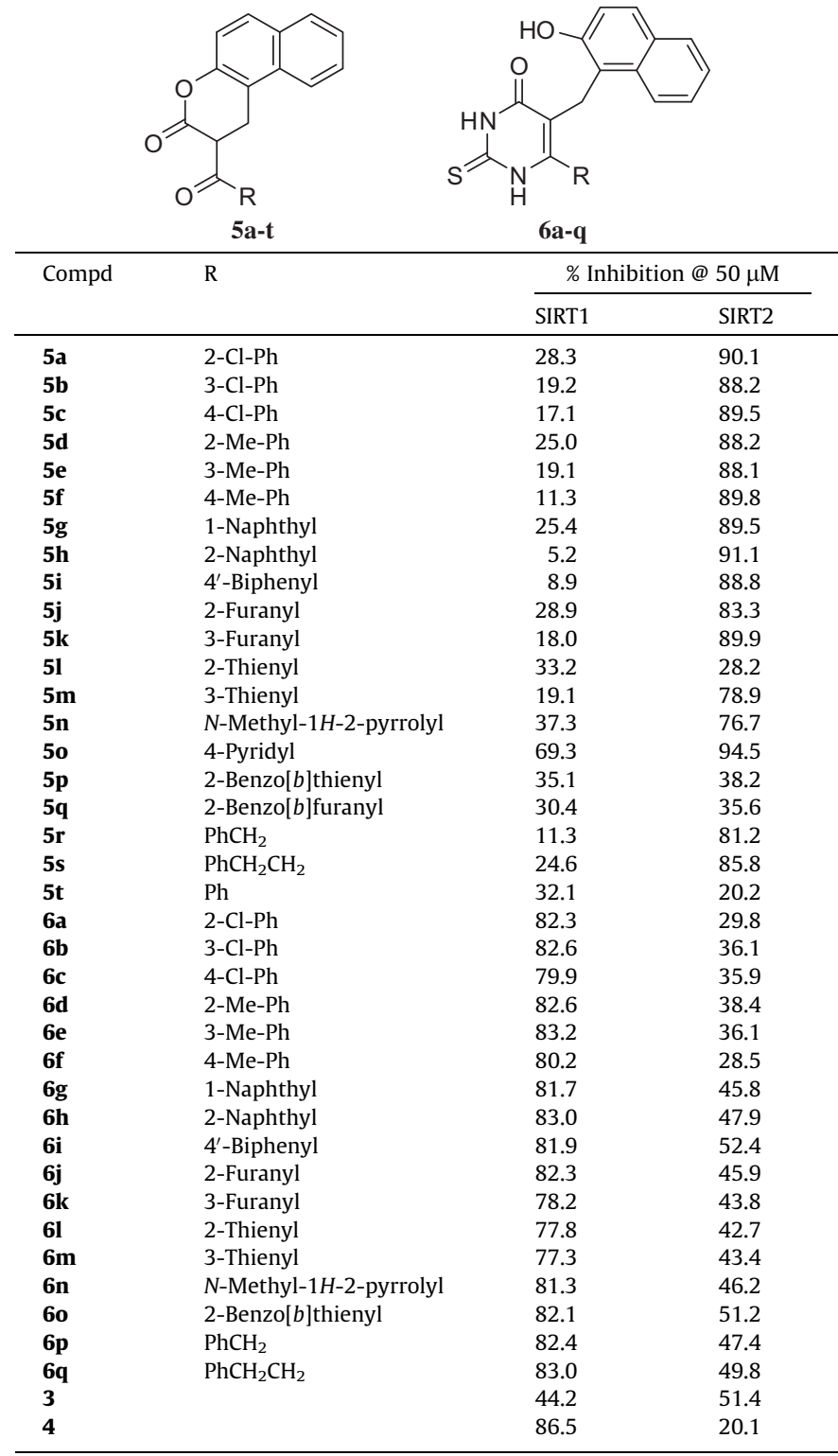

a Data are reported as the percent of inhibition at a concentration of $50 \mu \mathrm{M}$ relative to the control reaction with no added inhibitor. Data are reported as the average of three independent determinations; standard deviation of the average is $\leqslant 5 \%$.

Table 3

$\mathrm{IC}_{50}$ values of selected $\mathbf{5}$ and $\mathbf{6}$ compounds

\begin{tabular}{lcc}
\hline \multirow{2}{*}{ Compd } & \multicolumn{2}{c}{$\mathrm{IC}_{50}(\mu \mathrm{M}) \pm \mathrm{SD}$} \\
\cline { 2 - 3 } & $\mathrm{SIRT} 1$ & $\mathrm{SIRT} 2$ \\
\hline $\mathbf{5 a}$ & $89.8 \pm 9.4$ & $9.4 \pm 1.2$ \\
$\mathbf{5 h}$ & $\mathrm{ND}^{\mathrm{a}}$ & $8.9 \pm 1.1$ \\
$\mathbf{5 i}$ & $\mathrm{ND}$ & $10.0 \pm 1.3$ \\
$\mathbf{5 t}$ & $112.0 \pm 3.5$ & $178.7 \pm 24.6$ \\
$\mathbf{6 h}$ & $12.4 \pm 1.5$ & $49.9 \pm 9.5$ \\
$\mathbf{6 q}$ & $17.5 \pm 2.4$ & $50.8 \pm 11.2$ \\
$\mathbf{3}$ & $57.9 \pm 14.7$ & $40.7 \pm 10.4$ \\
$\mathbf{4}$ & $8.4 \pm 0.2$ & $191.2 \pm 25.6$ \\
\hline
\end{tabular}

a ND, not determined.

modest selectivity towards SIRT1, but they are devoid of structure-activity relationship. $\mathrm{IC}_{50}$ values calculated for the selected $\mathbf{6}$ derivatives $\mathbf{6 h}$ and $\mathbf{6 q}$ confirmed this trend of activity (Table 3 ). 

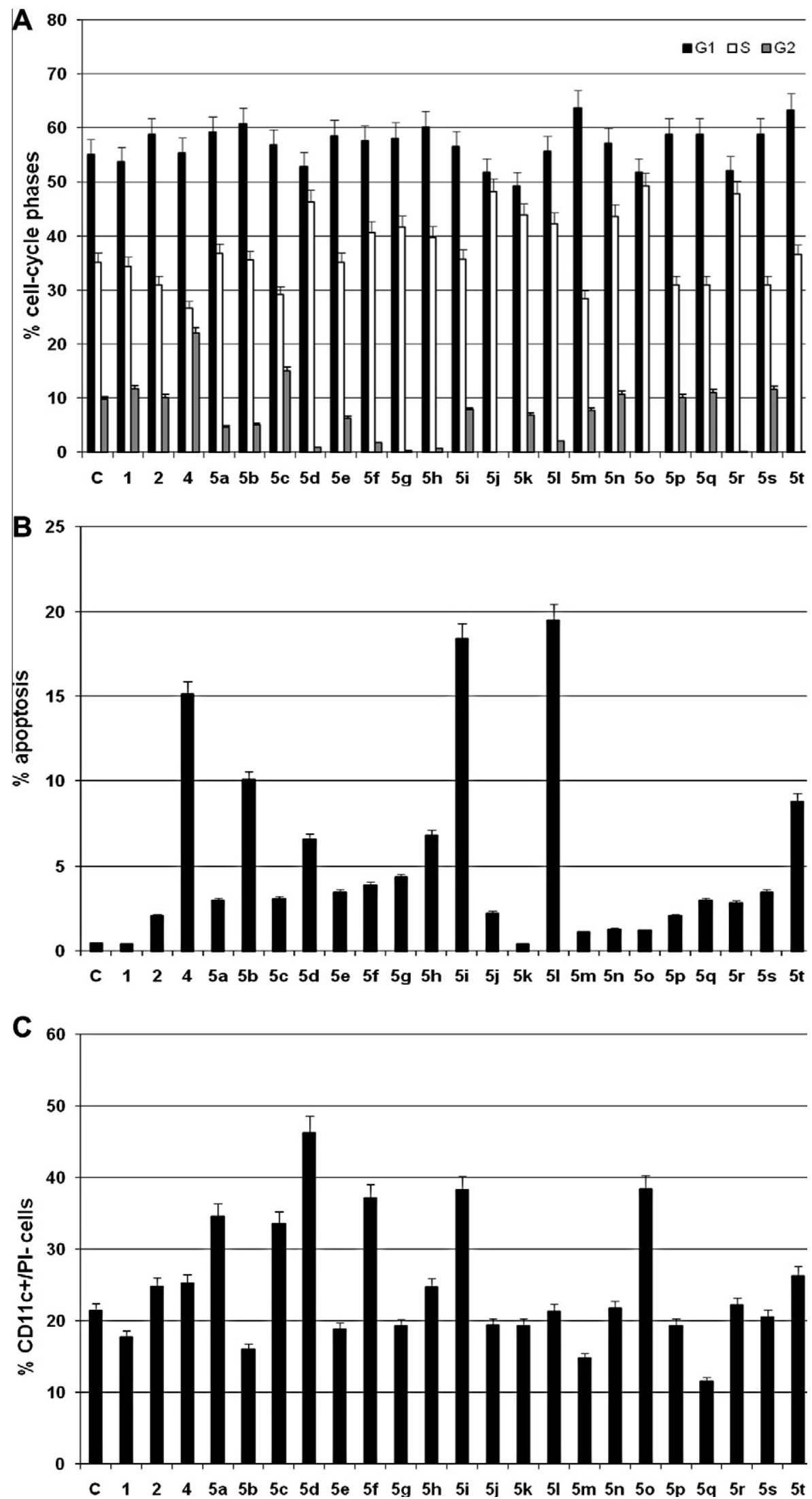

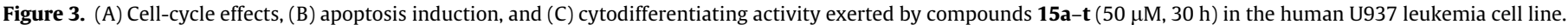



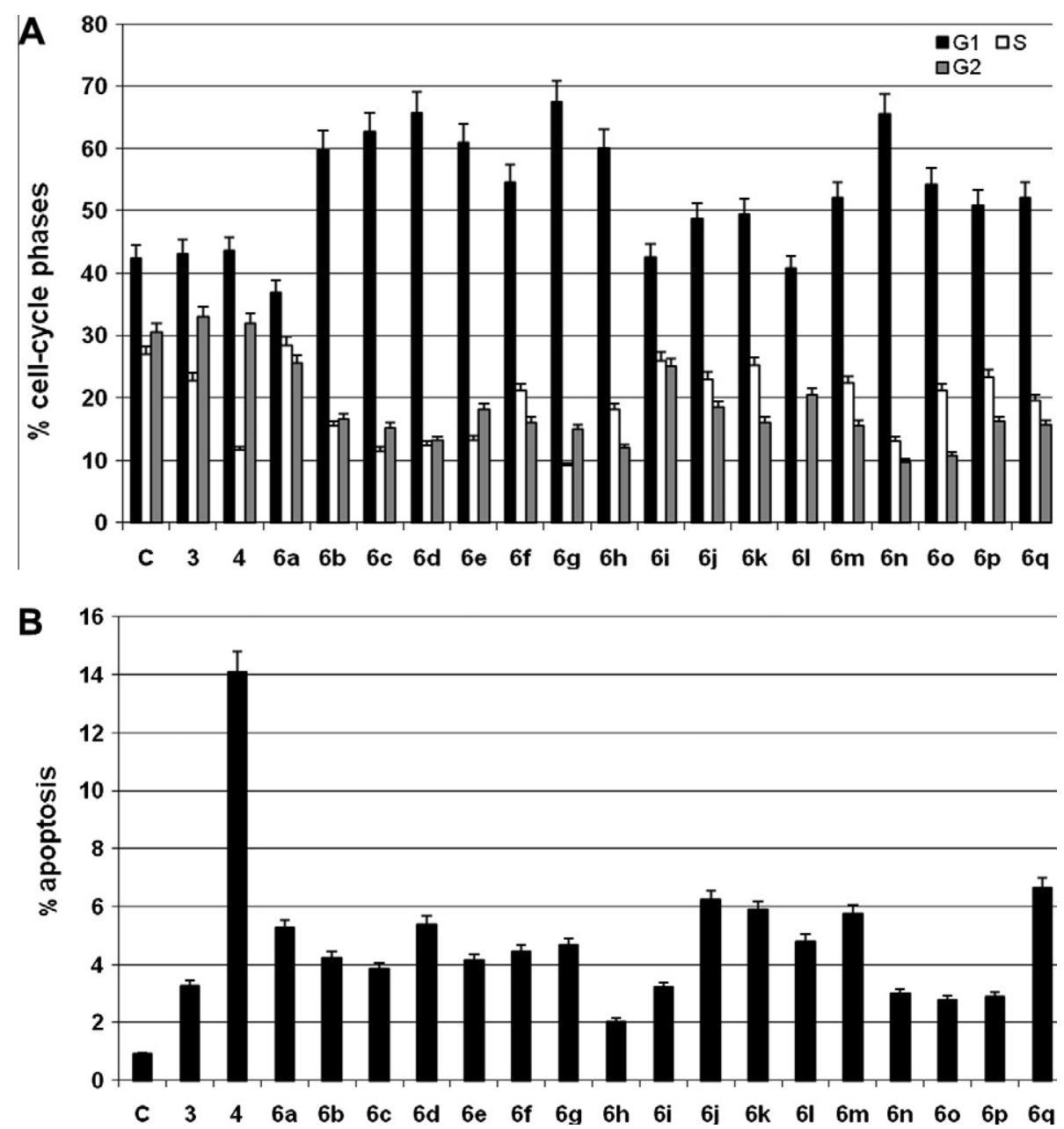

Figure 4. (A) Cell-cycle effects and (B) apoptosis induction exerted by compounds 16a-q (50 $\mu \mathrm{M}, 30 \mathrm{~h}$ ) in the human U937 leukemia cell line.

\subsection{Cell-based studies}

The two series of derivatives $\mathbf{5 a - t}$ and $\mathbf{6 a - q}$ were tested at $50 \mu \mathrm{M}$ for $30 \mathrm{~h}$ in human U937 leukemia cells, together with splitomicin (1), HR-73 (2), cambinol (3), and 4 as reference drugs at the same concentration, to determine their effects on cell-cycle, apoptosis induction (measured as caspase 3-7 activation), and granulocytic differentiation (measured as CD11c expression). In U937 cells, none of the tested compounds showed significant cytotoxicity up to $50 \mu \mathrm{M}$.

As regards to their effect on U937 cell-cycle, most of compounds $\mathbf{5}$ (in particular, $\mathbf{5 j}, \mathbf{h}, \mathbf{j}, \mathbf{m}, \mathbf{o}, \mathbf{r}, \mathbf{t}$ ) elicited cell-cycle arrest at the $G_{1} / S$ phase, while $\mathbf{5 c}$ displayed a block at the $G_{2} / M$ phase similar to that exerted by 4 (Fig. 3A). The FACS analysis for apoptosis indicated that the majority of $\mathbf{5}$ were able to induce programmed cell death more efficiently than the related coumarin derivatives $\mathbf{1}$ and $\mathbf{2}$, with compounds $\mathbf{5 i}$ and $\mathbf{5 1}$ being the most efficient ( $18.4 \%$ and $19.5 \%$ of apoptosis, respectively; Fig. 3B) and even stronger than the parent compound MC2141 (4). Nevertheless, at least for $\mathbf{5 1}$ such apoptotic property seems to be unrelated to SIRT inhibition. In the CD11c test to evaluate the effects on granulocytic differentiation, six compounds (5a, c, $\mathbf{d}, \mathbf{f}, \mathbf{i}, \mathbf{o}$ ) displayed an induction of differentiation $>30 \%$, with the derivative $\mathbf{5 d}$ being the most efficient (46.2\% of CD11c positive/propidium iodide (PI) negative cells) and much more active than the parent compound $\mathbf{4}$ and the coumarin analogues $\mathbf{1}$ and $\mathbf{2}$ (Fig. 3C). To reach high differentiation property in U937 cells, the insertion of a chloro or methyl or phenyl substituent at the 2 or 4 position (not 3 !) of the phenyl ring at the $\mathrm{C} 2$ position of the coumarin scaffold, as well as the replacement of this phenyl moiety with a 4-pyridyl residue seems to be important (compare 5a, c, $\mathbf{d}, \mathbf{f}, \mathbf{i}, \mathbf{o}$ with the unsubstituted prototype $\mathbf{5 t}$ ). On the contrary, replacement of the same phenyl ring with a five-member heterocycle such as furan, thiophene, and pyrrole as well as with bulkier naphthyl or 2-benzo[b]thienyl/2benzo[b]furanyl rings, or introduction of methylene unit(s) between the carbonyl group and the phenyl ring at the $\mathrm{C} 2$ position of the coumarin base led to scarcely or no active compounds in this test.

Most of the compounds of the second series $(\mathbf{6} \mathbf{a}-\mathbf{q})$ elicited a significant cell-cycle arrest at the $G_{1}$ phase, particularly evident with the derivatives $\mathbf{6 b}-\mathbf{h}, \mathbf{n}$ (Fig. 4A). The FACS analysis for apoptosis showed that the majority of $\mathbf{6 a}-\mathbf{q}$ were able to induce an apoptosis level similar to that obtained by 3 . Nevertheless, even the most efficient derivatives $\mathbf{6} \mathbf{j}, \mathbf{k}, \mathbf{q}$ were less potent than the parent compound $\mathbf{4}$ in this cell line at the described conditions. Moreover, no link to cellular sirtuin inhibition has been established. In the CD11c test to evaluate the effects of compounds $\mathbf{6 a - q}$ on granulocytic differentiation, none of the compounds including reference compounds $\mathbf{3}$ and $\mathbf{4}$ showed a significant induction of differentiation (Fig. S1 in the Supplementary data).

\section{Conclusion}

In the present study, we describe the development of two series of simplification products of the previously reported SIRT1 selective inhibitor MC2141 (4). ${ }^{39}$ 
The first series comprises several coumarin derivatives (5a-t), also related to the well known SIRTi splitomicin (1) ${ }^{40}$ and HR-73 (2), ${ }^{41}$ that depending on the profile of substitution at the 2-position of the 1,2-dihydrobenzo[f]chromen-3-one common scaffold showed a selectivity for inhibition of SIRT2 over SIRT1. Two of these compounds (5i and $\mathbf{5 l}$ ) displayed promising pro-apoptotic properties in a human leukemia cell line (U937), that seems (at least for 5l) to be unrelated to their SIRT inhibition. Some of them (5d, 5i, and 5o) were endowed with high cytodifferentiation properties in the same cell line (U937). The second group of derivatives consists of a series of 3-analogues, characterized by various substitutions at the C- 6 position of the pyrimidine ring of the prototype and that, differently from the unselective SIRTi 3, displayed a selective inhibition of SIRT1 over SIRT2, similarly to the parent tetracyclic compound 4. In U937 cells, selected compounds $(\mathbf{6 j}, \mathbf{6 k}$, and $\mathbf{6 q )}$ of this series were more efficient than $\mathbf{3}$ but less than $\mathbf{4}$ to induce apoptosis.

\section{Experimental section}

\subsection{Chemistry}

Melting points were determined on a Buchi 530 melting point apparatus and are uncorrected. ${ }^{1} \mathrm{H}$ NMR spectra were recorded at $400 \mathrm{MHz}$ on a Bruker AC 400 spectrometer; chemical shifts are reported in ppm units relative to the internal reference tetramethylsilane $\left(\mathrm{Me}_{4} \mathrm{Si}\right)$. All the compounds were routinely checked by TLC and ${ }^{1} \mathrm{H}$ NMR. TLC was performed on aluminum backed silica gel plates (Merck DC, Alufolien Kieselgel 60 F254) with spots visualized by UV light. All of the solvents were reagent grade and, when necessary, were purified and dried by standard methods. Concentration of solutions after reactions and extractions involved the use of a rotary evaporator operating at a reduced pressure of ca. 20 Torr. Organic solutions were dried over anhydrous sodium sulfate. Analytical results are within $\pm 0.40 \%$ of the theoretical values. All the chemicals were purchased from Aldrich Chimica, Milan (Italy) or from Lancaster Synthesis GmbH, Milan (Italy), and were of the highest purity.

\subsubsection{General procedure for the synthesis of 2-substituted-3H- benzo[f]chromen-3-ones (8a-s). Example: 2-(3-thienyl)-3H- benzo[f]chromen-3-one $(8 \mathrm{~m})$}

Catalytic amounts of piperidine and acetic acid were added to a mixture of 2-hydroxy-1-naphthaldehyde $(2.15 \mathrm{~g}, 12.5 \mathrm{mmol})$ and 3-oxo-3-thiophen-3-yl-propionic acid ethyl ester $(2.97 \mathrm{~g}$, $14.9 \mathrm{mmol})$ in dry ethanol $(66 \mathrm{~mL})$. The solution was then stirred at reflux temperature for $5 \mathrm{~h}$. After completion of the reaction, the cooled suspension was filtered off and the crude yellow solid was purified by recrystallization. ${ }^{1} \mathrm{H}$ NMR $\left(\mathrm{CDCl}_{3}\right) \delta 7.35(\mathrm{~m}, 1 \mathrm{H}$, $H$ thiophene ring), 7.48 (d, $1 \mathrm{H}, H$ naphthalene ring), 7.57-7.63 $(\mathrm{m}, 2 \mathrm{H}, \mathrm{H}$ thiophene and naphthalene rings), $7.70(\mathrm{t}, 1 \mathrm{H}, \mathrm{H}$ naphthalene ring), 7.92 (d, $1 \mathrm{H}, H$ naphthalene ring), 8.07 (d, $1 \mathrm{H}, H$ naphthalene ring), $8.13(\mathrm{~m}, 1 \mathrm{H}, \mathrm{H}$ thiophene ring), $8.23(\mathrm{~d}, 1 \mathrm{H}, \mathrm{H}$ naphthalene ring), $8.88(\mathrm{~s}, 1 \mathrm{H},=\mathrm{CH}-)$.

4.1.2. General procedure for the synthesis of 2-substituted-1,2dihydrobenzo[f]chromen-3-ones (5a-t). Example: 2-(1-methyl1H-pyrrole-2-carbonyl)-1,2-dihydro-benzo[f]chromen-3-one (5n)

Compound $8 \mathrm{n}$ ( $1.0 \mathrm{~g}, 3.29 \mathrm{mmol}, 1$ equiv) was dissolved in dry pyridine $(25 \mathrm{~mL})$ at $0^{\circ} \mathrm{C}$, and $\mathrm{NaBH}_{4}(125 \mathrm{mg}, 3.29 \mathrm{mmol}, 1$ equiv $)$ was added to the solution. The mixture was stirred at $0{ }^{\circ} \mathrm{C}$ for $1 \mathrm{~h}$ and then at room temperature for $4 \mathrm{~h}$. Afterward, the reaction was poured into $1 \mathrm{~N} \mathrm{HCl}(125 \mathrm{~mL})$, and the obtained precipitate was filtered off and subsequently washed with $\mathrm{H}_{2} \mathrm{O}(3 \times 30 \mathrm{~mL})$ and purified by recrystallization yielding the desired pure compound 5n. ${ }^{1} \mathrm{H}$ NMR $\left(\mathrm{CDCl}_{3}\right) \delta 3.59(\mathrm{~m}, 1 \mathrm{H}, \mathrm{HCHCH}(\mathrm{CO}) \mathrm{COO}), 3.76$ $(\mathrm{m}, 1 \mathrm{H}, \mathrm{HCHCH}(\mathrm{CO}) \mathrm{COO}), 3.93\left(\mathrm{~s}, 1 \mathrm{H}, \mathrm{NCH}_{3}\right), 4.54(\mathrm{~m}, 1 \mathrm{H}$, $\left.\mathrm{CH}_{2} \mathrm{CH}(\mathrm{CO}) \mathrm{COO}\right), 6.17(\mathrm{~m}, 1 \mathrm{H}, \mathrm{H}$ pyrrole ring), $6.89(\mathrm{~m}, 1 \mathrm{H}, \mathrm{H}$ pyrrole ring), $7.02(\mathrm{~m}, 1 \mathrm{H}, H$ pyrrole ring), $7.25(\mathrm{~d}, 1 \mathrm{H}, H$ naphthalene ring), 7.45 (t, $1 \mathrm{H}, H$ naphthalene ring), $7.54(\mathrm{t}, 1 \mathrm{H}, H$ naphthalene ring), 7.76-7.87 ( $\mathrm{m}, 3 \mathrm{H}, \mathrm{H}$ naphthalene ring).

4.1.2.1. 2-(1-Naphthoyl)-1,2-dihydro-benzo[f]chromen-3-one (5g). ${ }^{1} \mathrm{H} \mathrm{NMR}\left(\mathrm{CDCl}_{3}\right) \delta 3.59(\mathrm{~m}, 1 \mathrm{H}, \mathrm{HCHCH}(\mathrm{CO}) \mathrm{COO}), 3.85(\mathrm{~m}$, $1 \mathrm{H}, \mathrm{HCHCH}(\mathrm{CO}) \mathrm{COO}), 4.84\left(\mathrm{~m}, 1 \mathrm{H}, \mathrm{CH}_{2} \mathrm{CH}(\mathrm{CO}) \mathrm{COO}\right), 7.25(\mathrm{~m}, 1 \mathrm{H}$, $H$ naphthalene rings), $7.40-7.53(\mathrm{~m}, 5 \mathrm{H}, H$ naphthalene rings), 7.73-8.02 ( $\mathrm{m}, 6 \mathrm{H}, \mathrm{H}$ naphthalene rings), 8.19 (d, $1 \mathrm{H}, H$ naphthalene ring).

4.1.2.2. 2-(2-Naphthoyl)-1,2-dihydro-benzo[f]chromen-3-one (5h). ${ }^{1} \mathrm{H}$ NMR $\left(\mathrm{CDCl}_{3}\right) \delta 3.61(\mathrm{~m}, 1 \mathrm{H}, \mathrm{HCHCH}(\mathrm{CO}) \mathrm{COO}), 3.86(\mathrm{~m}$, $1 \mathrm{H}, \mathrm{HCHCH}(\mathrm{CO}) \mathrm{COO}), 4.82\left(\mathrm{~m}, 1 \mathrm{H}, \mathrm{CH}_{2} \mathrm{CH}(\mathrm{CO}) \mathrm{COO}\right), 7.29$ (d, $1 \mathrm{H}$, $H$ naphthalene ring), 7.44-7.62 ( $\mathrm{m}, 4 \mathrm{H}, \mathrm{H}$ naphthalene rings), 7.79-7.96 ( $\mathrm{m}, 6 \mathrm{H}, H$ naphthalene rings), 8.03 ( $\mathrm{m}, 1 \mathrm{H}, H$ naphthalene ring), 8.51 ( $\mathrm{s}, 1 \mathrm{H}, H$ naphthalene ring).

4.1.2.3. 2-(4'-Biphenylcarbonyl)-1,2-dihydro-benzo[f]chromen3-one (5i). ${ }^{1} \mathrm{H}$ NMR $\left(\mathrm{CDCl}_{3}\right) \delta 3.61(\mathrm{~m}, 1 \mathrm{H}, \mathrm{HCHCH}(\mathrm{CO}) \mathrm{COO}), 3.83$ $(\mathrm{m}, 1 \mathrm{H}, \mathrm{HCHCH}(\mathrm{CO}) \mathrm{COO}), 4.82\left(\mathrm{~m}, 1 \mathrm{H}, \mathrm{CH}_{2} \mathrm{CH}(\mathrm{CO}) \mathrm{COO}\right), 7.27$ (d, $1 \mathrm{H}, H$ naphthalene ring), 7.37-7.62 $(\mathrm{m}, 7 \mathrm{H}, \mathrm{H}$ biphenyl and naphthalene rings), 7.70 ( $\mathrm{m}, 2 \mathrm{H}, \mathrm{H}$ biphenyl and naphthalene rings), 7.78-7.88 ( $\mathrm{m}, 3 \mathrm{H}, H$ biphenyl and naphthalene rings), $8.06(\mathrm{~m}$, $2 \mathrm{H}, \mathrm{H}$ biphenyl and naphthalene rings).

4.1.2.4. 2-(Furan-3-carbonyl)-1,2-dihydro-benzo[f]chromen-3one (5k). ${ }^{1} \mathrm{H}$ NMR $\left(\mathrm{CDCl}_{3}\right) \delta 3.55(\mathrm{~m}, 1 \mathrm{H}, \mathrm{HCHCH}(\mathrm{CO}) \mathrm{COO}), 3.82$ $(\mathrm{m}, 1 \mathrm{H}, \mathrm{HCHCH}(\mathrm{CO}) \mathrm{COO}), 4.35\left(\mathrm{~m}, 1 \mathrm{H}, \mathrm{CH}_{2} \mathrm{CH}(\mathrm{CO}) \mathrm{COO}\right), 6.80(\mathrm{~m}$, $1 \mathrm{H}, H$ furan ring), 7.23 (d, $1 \mathrm{H}, H$ naphthalene ring), 7.46-7.50 (m, $2 \mathrm{H}, H$ furan and naphthalene rings), $7.56(\mathrm{t}, 1 \mathrm{H}, H$ naphthalene ring), 7.76-7.90 (m, 3H, $H$ naphthalene ring), 8.17 (s, $1 \mathrm{H}, H$ furan ring).

4.1.2.5. 2-(Thiophene-2-carbonyl)-1,2-dihydro-benzo[f]chromen3-one (51). ${ }^{1} \mathrm{H}$ NMR $\left(\mathrm{CDCl}_{3}\right) \delta 3.60(\mathrm{~m}, 1 \mathrm{H}, \mathrm{HCHCH}(\mathrm{CO}) \mathrm{COO})$, $3.83(\mathrm{~m}, 1 \mathrm{H}, \mathrm{HCHCH}(\mathrm{CO}) \mathrm{COO}), 4.61\left(\mathrm{~m}, 1 \mathrm{H}, \mathrm{CH}_{2} \mathrm{CH}(\mathrm{CO}) \mathrm{COO}\right), 7.16$ $(\mathrm{m}, 1 \mathrm{H}, H$ thiophene ring), $7.24(\mathrm{~d}, 1 \mathrm{H}, H$ naphthalene ring), $7.46(\mathrm{t}, 1 \mathrm{H}, H$ naphthalene ring $), 7.55(\mathrm{t}, 1 \mathrm{H}, H$ naphthalene ring), $7.72(\mathrm{~m}, 1 \mathrm{H}, H$ naphthalene ring), $7.78(\mathrm{~m}, 1 \mathrm{H}, H$ naphthalene ring), $7.82-7.88(\mathrm{~m}, 3 \mathrm{H}, \quad H$ thiophene and naphthalene rings).

4.1.2.6. 2-(Thiophene-3-carbonyl)-1,2-dihydro-benzo[f $]$ chromen-3-one (5m). ${ }^{1} \mathrm{H} \mathrm{NMR}\left(\mathrm{CDCl}_{3}\right) \delta 3.56(\mathrm{~m}, 1 \mathrm{H}, \mathrm{HCHCH}(\mathrm{CO}) \mathrm{COO})$, $3.81(\mathrm{~m}, 1 \mathrm{H}, \mathrm{HCHCH}(\mathrm{CO}) \mathrm{COO}), 4.59\left(\mathrm{~m}, 1 \mathrm{H}, \quad \mathrm{CH}_{2} \mathrm{CH}(\mathrm{CO})-\right.$ $\mathrm{COO}), 7.23(\mathrm{~d}, 1 \mathrm{H}, H$ naphthalene ring), $7.34(\mathrm{~m}, 1 \mathrm{H}, H$ thiophene ring), 7.46 ( $\mathrm{t}, 1 \mathrm{H}, \mathrm{H}$ naphthalene ring), 7.53-7.57 ( $\mathrm{m}, 2 \mathrm{H}, H$ thiophene and naphthalene rings), $7.78(\mathrm{~m}, 1 \mathrm{H}, \mathrm{H}$ naphthalene ring), $7.83-7.88$ ( $\mathrm{m}, 2 \mathrm{H}, \mathrm{H}$ naphthalene ring), 8.19 ( $\mathrm{m}, 1 \mathrm{H}, H$ thiophene ring).

4.1.2.7. 2-(Pyridine-4-carbonyl)-1,2-dihydro-benzo[f $]$ chromen3-one (5o). ${ }^{1} \mathrm{H}$ NMR $\left(\mathrm{CDCl}_{3}\right) \delta 3.63(\mathrm{~m}, 1 \mathrm{H}, \mathrm{HCHCH}(\mathrm{CO}) \mathrm{COO}), 3.77$ ( $\mathrm{m}, 1 \mathrm{H}, \mathrm{HCHCH}(\mathrm{CO}) \mathrm{COO}), 4.71\left(\mathrm{~m}, 1 \mathrm{H}, \mathrm{CH}_{2} \mathrm{CH}(\mathrm{CO}) \mathrm{COO}\right), 7.24(\mathrm{~m}$, $1 \mathrm{H}, \mathrm{H}$ naphthalene ring), 7.43-7.61 $(\mathrm{m}, 4 \mathrm{H}, \mathrm{H}$ pyridine and naphthalene rings), $7.74-7.88(\mathrm{~m}, 3 \mathrm{H}, H$ pyridine and naphthalene rings), 8.84 ( $\mathrm{m}, 2 \mathrm{H}$, pyridine ring).

4.1.2.8. 2-(Benzo[b]thiophene-2-carbonyl)-1,2-dihydro-benzo[f]chromen-3-one (5p). ${ }^{1} \mathrm{H}$ NMR $\left(\mathrm{CDCl}_{3}\right) \quad \delta \quad 3.67 \quad(\mathrm{~m}, 1 \mathrm{H}$, $\mathrm{HCHCH}(\mathrm{CO}) \mathrm{COO}), 3.86(\mathrm{~m}, 1 \mathrm{H}, \mathrm{HCHCH}(\mathrm{CO}) \mathrm{COO}), 4.74(\mathrm{~m}, 1 \mathrm{H}$, 
$\mathrm{CH}_{2} \mathrm{CH}(\mathrm{CO}) \mathrm{COO}$ ), 7.24-7.27 (m, $1 \mathrm{H}, \mathrm{H}$ naphthalene ring), 7.40 (t, $1 \mathrm{H}, H$ benzothiophene ring), 7.46-7.49 ( $\mathrm{m}, 2 \mathrm{H}, \mathrm{H}$ benzothiophene and naphthalene rings), $7.56(\mathrm{t}, 1 \mathrm{H}, H$ benzothiophene ring), 7.80 (d, $1 \mathrm{H}, H$ naphthalene ring), 7.84-7.90 ( $\mathrm{m}, 4 \mathrm{H}, \mathrm{H}$ benzothiophene and naphthalene rings), $8.10(\mathrm{~s}, 1 \mathrm{H}, H$ benzothiophene ring).

4.1.2.9. 2-(Benzofuran-2-carbonyl)-1,2-dihydro-benzo[f]chromen-3-one (5q). ${ }^{1} \mathrm{H}$ NMR $\left(\mathrm{CDCl}_{3}\right) \delta 3.65(\mathrm{~m}, 1 \mathrm{H}, \mathrm{HCHCH}(\mathrm{CO})-$ $\mathrm{COO}), 3.83(\mathrm{~m}, 1 \mathrm{H}, \mathrm{HCHCH}(\mathrm{CO}) \mathrm{COO}), 4.76\left(\mathrm{~m}, 1 \mathrm{H}, \mathrm{CH}_{2} \mathrm{CH}(\mathrm{CO})-\right.$ COO), $7.27(\mathrm{~d}, 1 \mathrm{H}, \mathrm{H}$ naphthalene ring), 7.31-7.33 (m, $1 \mathrm{H}, H$ benzofuran ring), 7.44-7.57 $(\mathrm{m}, 4 \mathrm{H}, \mathrm{H}$ benzofuran and naphthalene rings), $7.67(\mathrm{~d}, 1 \mathrm{H}, \mathrm{H}$ benzofuran ring), $7.71(\mathrm{~m}, 1 \mathrm{H}, \mathrm{H}$ naphthalene ring), $7.78-7.88(\mathrm{~m}, 3 \mathrm{H}, H$ benzofuran and naphthalene rings).

4.1.2.10. 2-(1-Hydroxy-2-phenylethylidene)-1H-benzo[f]chromen-3(2H)-one (5r). ${ }^{1} \mathrm{H}$ NMR $\left(\mathrm{CDCl}_{3}\right) \delta 3.84\left(\mathrm{~s}, 2 \mathrm{H}, \mathrm{CH}_{2} \mathrm{Ph}\right), 4.00$ $\left(\mathrm{s}, 2 \mathrm{H}, \mathrm{CH}_{2}\right), 7.19(\mathrm{~m}, 1 \mathrm{H}, H$ benzene ring), $7.26(\mathrm{~m}, 1 \mathrm{H}, H$ naphthalene ring), 7.33-7.38 ( $\mathrm{m}, 4 \mathrm{H}, \mathrm{H}$ benzene ring), $7.46(\mathrm{t}, 1 \mathrm{H}, \mathrm{H}$ naphthalene ring), 7.56 (t, $1 \mathrm{H}, H$ naphthalene ring), 7.70-7.74 (m, $2 \mathrm{H}, \mathrm{H}$ naphthalene ring), $7.81(\mathrm{~d}, 1 \mathrm{H}, H$ naphthalene ring), $13.70(\mathrm{~s}, 1 \mathrm{H}$, $\mathrm{OH})$.

4.1.2.11. 2-(3-Phenylpropanoyl)-1H-benzo[f]chromen-3(2H)one (5s). ${ }^{1} \mathrm{H}$ NMR $\left(\mathrm{CDCl}_{3}\right) \delta 2.81\left(\mathrm{~m}, 2 \mathrm{H}, \mathrm{COCH}_{2}\right), 2.94(\mathrm{~m}, 2 \mathrm{H}$, $\left.\mathrm{COCH}_{2} \mathrm{CH}_{2}\right), \quad 3.62(\mathrm{~m}, 1 \mathrm{H}, \quad \mathrm{HCHCH}(\mathrm{CO}) \mathrm{COO}), 3.82(\mathrm{~m}, 1 \mathrm{H}$, $\mathrm{HCHCH}(\mathrm{CO}) \mathrm{COO}), 4.56\left(\mathrm{~m}, 1 \mathrm{H}, \mathrm{CH}_{2} \mathrm{CH}(\mathrm{CO}) \mathrm{COO}\right), 7.13-7.29(\mathrm{~m}$, $6 \mathrm{H}, H$ benzene and naphthalene rings), $7.45-7.48(\mathrm{~m}, 1 \mathrm{H}, H$ naphthalene ring), 7.53-7.58 ( $\mathrm{m}, 1 \mathrm{H}, \mathrm{H}$ naphthalene ring), 7.67-7.88 (m, $3 \mathrm{H}, \mathrm{H}$ benzene and naphthalene rings).

4.1.3. General procedure for the synthesis of 6-substituted-5-(2hydroxynaphthalen-1-ylmethyl)-2-thioxo-2,3-dihydro-1 H-pyrimidin-4-ones (6a-q). Example: 6-benzyl-5-(2-hydroxynaphthalen-1-ylmethyl)-2-thioxo-2,3-dihydro-1H-pyrimidin-4-one (6p)

Sodium metal ( $56 \mathrm{mg}, 2.45 \mathrm{mmol}, 2.5$ equiv) was dissolved in $6 \mathrm{~mL}$ of absolute ethanol, and thiourea $(149 \mathrm{mg}, 1.96 \mathrm{mmol}$, 2 equiv) and 2-phenylacetyl-1,2-dihydro-benzo[f]chromen-3-one (5r) (393 mg, $0.98 \mathrm{mmol}, 1$ equiv) were added to the clear solution. The mixture was heated at reflux for $2 \mathrm{~h}$. After the mixture was cooled, the solvent was distilled in vacuo at $40-50{ }^{\circ} \mathrm{C}$ until dry and the residue was dissolved in a little amount of water $(20 \mathrm{~mL})$ and made acidic with $2 \mathrm{~N} \mathrm{HCl}$. The resulting mixture was then extracted with ethyl acetate $(3 \times 30 \mathrm{~mL})$. The combined organic solutions were washed with brine $(2 \times 20 \mathrm{~mL})$, dried and evaporated to dryness. The residual crude was finally purified by column chromatography on silica gel eluting with a mixture ethyl acetate/nhexane $1: 1$. The obtained solid was recrystallized from chloroform to give pure $6 \mathrm{p}$. ${ }^{1} \mathrm{H}$ NMR (DMSO) $\delta 3.83\left(\mathrm{~s}, 2 \mathrm{H}, \mathrm{CH}_{2}\right.$ at C-6), $4.14(\mathrm{~s}$, $2 \mathrm{H}, \mathrm{CH}_{2}$ at $\left.\mathrm{C}-5\right), 6.86(\mathrm{~m}, 2 \mathrm{H}, \mathrm{H}$ benzene ring $), 7.01(\mathrm{~d}, 1 \mathrm{H}, \mathrm{H}$ naphthalene ring), $7.09(\mathrm{~m}, 3 \mathrm{H}, H$ benzene ring), $7.26(\mathrm{t}, 1 \mathrm{H}, H$ naphthalene ring), $7.37(\mathrm{t}, 1 \mathrm{H}, H$ naphthalene ring), $7.54(\mathrm{~d}, 1 \mathrm{H}, H$ naphthalene ring), $7.72(\mathrm{~d}, 1 \mathrm{H}, H$ naphthalene ring), $7.89(\mathrm{~d}, 1 \mathrm{H}$, $H$ naphthalene ring), $9.88(\mathrm{~s}, 1 \mathrm{H}, \mathrm{OH}), 12.04(\mathrm{~s}, 1 \mathrm{H}, \mathrm{NH}), 12.54(\mathrm{~s}$, $1 \mathrm{H}, \mathrm{NH})$.

4.1.3.1. 6-(2-Chlorophenyl)-5-[(2-hydroxynaphthalen-1-yl)methyl]2-thioxo-2,3-dihydropyrimidin-4(1H)-one (6a). ${ }^{1} \mathrm{H}$ NMR (DMSO) $\delta 3.86(\mathrm{~d}, 1 \mathrm{H}, \mathrm{CHH}$ at C-5), $3.97(\mathrm{~d}, 1 \mathrm{H}, \mathrm{CHH}$ at C-5), 6.86 (d, $1 \mathrm{H}, H$ benzene ring), $6.96(\mathrm{~d}, 1 \mathrm{H}, H$ naphthalene ring), 7.01 ( $\mathrm{m}, 1 \mathrm{H}, \mathrm{H}$ benzene ring), 7.12-7.20 ( $\mathrm{m}, 2 \mathrm{H}, \mathrm{H}$ benzene and naphthalene rings), $7.24-7.30(\mathrm{~m}, 2 \mathrm{H}, H$ benzene and naphthalene rings), 7.46-7.50 (m, 2H, $H$ naphthalene ring), $7.65(\mathrm{~d}, 1 \mathrm{H}, H$ naphthalene ring), $9.18(\mathrm{~s}, 1 \mathrm{H}, \mathrm{OH}), 12.31(\mathrm{~s}, 1 \mathrm{H}, \mathrm{NH}), 12.66(\mathrm{~s}$, $1 \mathrm{H}, \mathrm{NH})$.
4.1.3.2. 5-[(2-Hydroxynaphthalen-1-yl)methyl]-6-(naphthalen1-yl)-2-thioxo-2,3-dihydropyrimidin-4(1H)-one (6g). ${ }^{1} \mathrm{H}$ NMR (DMSO) $\delta 3.77(\mathrm{~d}, 1 \mathrm{H}, \mathrm{CHH}$ at C-5), $3.94(\mathrm{~d}, 1 \mathrm{H}, \mathrm{CHH}$ at C-5), 6.56 (d, $1 \mathrm{H}, H$ naphthalene ring), 7.07-7.44 $(\mathrm{m}, 10 \mathrm{H}, \mathrm{H}$ naphthalene rings), $7.78(\mathrm{~m}, 2 \mathrm{H}, \mathrm{H}$ naphthalene ring), $9.07(\mathrm{~s}, 1 \mathrm{H}, \mathrm{OH}), 12.36$ (s, 1H, NH), $12.68(\mathrm{~s}, 1 \mathrm{H}, \mathrm{NH})$.

4.1.3.3. 5-[(2-Hydroxynaphthalen-1-yl)methyl]-6-(naphthalen2-yl)-2-thioxo-2,3-dihydropyrimidin-4(1H)-one (6h). ${ }^{1} \mathrm{H}$ NMR (DMSO) $\delta 3.98\left(\mathrm{~s}, 2 \mathrm{H}, \mathrm{CH}_{2}\right.$ at $\left.\mathrm{C}-5\right), 6.81(\mathrm{~d}, 1 \mathrm{H}, \mathrm{H}$ naphthalene ring), 7.09 ( $\mathrm{m}, 2 \mathrm{H}, H$ naphthalene rings), 7.28 (d, $1 \mathrm{H}, H$ naphthalene ring), 7.37-7.43 ( $\mathrm{m}, 2 \mathrm{H}, H$ naphthalene rings), 7.53-7.60 (m, 3H, $H$ naphthalene rings), $7.80(\mathrm{~d}, 1 \mathrm{H}, \mathrm{H}$ naphthalene ring), 7.87-7.90 $(\mathrm{m}, 3 \mathrm{H}$, $H$ naphthalene rings), $9.41(\mathrm{~s}, 1 \mathrm{H}, \mathrm{OH}), 12.39(\mathrm{~s}, 1 \mathrm{H}, \mathrm{NH}), 12.59(\mathrm{~s}$, $1 \mathrm{H}, \mathrm{NH})$.

4.1.3.4. 6-(Biphenyl-4-yl)-5-[(2-hydroxynaphthalen-1-yl)methyl]2-thioxo-2,3-dihydropyrimidin- $4(\mathbf{1 H})$-one $\quad(6 \mathbf{6 i}) .{ }^{1} \mathrm{H} \quad \mathrm{NMR}$ (DMSO) $\delta 3.98\left(\mathrm{~s}, 2 \mathrm{H}, \mathrm{CH}_{2}\right.$ at $\left.\mathrm{C}-5\right), 6.86$ (d, $1 \mathrm{H}, \mathrm{H}$ biphenyl ring), 7.13-7.17 ( $\mathrm{m}, 1 \mathrm{H}, H$ naphthalene ring), 7.21-7.26 ( $\mathrm{m}, 3 \mathrm{H}, \mathrm{H}$ biphenyl and naphthalene rings), 7.38-7.51 ( $\mathrm{m}, 7 \mathrm{H}, \mathrm{H}$ biphenyl and naphthalene rings), 7.62-7.64 (m, $3 \mathrm{H}, \mathrm{H}$ biphenyl and naphthalene rings), $9.44(\mathrm{~s}, 1 \mathrm{H}, \mathrm{OH}), 12.29(\mathrm{~s}, 1 \mathrm{H}, \mathrm{NH}), 12.57(\mathrm{~s}, 1 \mathrm{H}, \mathrm{NH})$.

4.1.3.5. 6-(Furan-2-yl)-5-[(2-hydroxynaphthalen-1-yl)methyl]2-thioxo-2,3-dihydropyrimidin-4(1H)-one $\quad(6 \mathbf{j}) .{ }^{1} \mathrm{H} \quad \mathrm{NMR}$ (DMSO) $\delta 4.22\left(\mathrm{~s}, 2 \mathrm{H}, \mathrm{CH}_{2}\right.$ at $\left.\mathrm{C}-5\right), 6.56(\mathrm{~m}, 1 \mathrm{H}, \mathrm{H}$ furan ring), $7.00(\mathrm{~d}, 1 \mathrm{H}, H$ naphthalene ring), 7.04 (d, $1 \mathrm{H}, H$ furan ring), 7.22 (t, $1 \mathrm{H}, H$ naphthalene ring), $7.32(\mathrm{t}, 1 \mathrm{H}, H$ naphthalene ring), 7.56 (d, $1 \mathrm{H}, H$ naphthalene ring), 7.68-7.71 ( $\mathrm{m}, 2 \mathrm{H}, \mathrm{H}$ naphthalene ring), $7.77(\mathrm{~m}, 1 \mathrm{H}, \mathrm{H}$ furan ring), $9.49(\mathrm{~s}, 1 \mathrm{H}, \mathrm{OH}), 12.07(\mathrm{~s}, 1 \mathrm{H}, \mathrm{NH}), 12.51$ (s, $1 \mathrm{H}, \mathrm{NH})$.

4.1.3.6. 6-(Furan-3-yl)-5-[(2-hydroxynaphthalen-1-yl)methyl]2-thioxo-2,3-dihydropyrimidin-4(1H)-one (6k). ${ }^{1} \mathrm{H} \quad$ NMR (DMSO) $\delta 4.03\left(\mathrm{~s}, 2 \mathrm{H}, \mathrm{CH}_{2}\right.$ at $\left.\mathrm{C}-5\right), 6.53(\mathrm{~m}, 1 \mathrm{H}, \mathrm{H}$ furan ring), 7.01 (d, $1 \mathrm{H}, H$ naphthalene ring), $7.22(\mathrm{t}, 1 \mathrm{H}, H$ naphthalene ring) 7.29 (t, $1 \mathrm{H}, H$ naphthalene ring), 7.56-7.60 ( $\mathrm{m}, 2 \mathrm{H}, H$ naphthalene ring), $7.65(\mathrm{~m}, 1 \mathrm{H}, H$ furan ring), $7.70(\mathrm{~d}, 1 \mathrm{H}, H$ naphthalene ring), $7.99(\mathrm{~s}, 1 \mathrm{H}, \mathrm{H}$ furan ring), $9.52(\mathrm{~s}, 1 \mathrm{H}, \mathrm{OH}), 12.17(\mathrm{~s}, 1 \mathrm{H}, \mathrm{NH}), 12.48$ (s, $1 \mathrm{H}, \mathrm{NH})$.

4.1.3.7. 5-[(2-Hydroxynaphthalen-1-yl)methyl]-6-(thiophen-2yl)-2-thioxo-2,3-dihydropyrimidin-4(1H)-one (61). ${ }^{1} \mathrm{H} \quad \mathrm{NMR}$ (DMSO) $\delta 4.03\left(\mathrm{~s}, 2 \mathrm{H}, \mathrm{CH}_{2}\right.$ at $\left.\mathrm{C}-5\right), 6.96-7.03(\mathrm{~m}, 2 \mathrm{H}, \mathrm{H}$ thiophene and naphthalene rings), 7.18-7.22 (t, $1 \mathrm{H}, \mathrm{H}$ naphthalene ring), 7.27-7.29 ( $\mathrm{m}, 2 \mathrm{H}, \mathrm{H}$ thiophene and naphthalene rings), 7.54-7.58 ( $\mathrm{m}, 2 \mathrm{H}, H$ naphthalene ring), 7.66-7.70 ( $\mathrm{m}, 2 \mathrm{H}, H$ thiophene and naphthalene rings), $9.47(\mathrm{~s}, 1 \mathrm{H}, \mathrm{OH}), 12.28(\mathrm{~s}, 1 \mathrm{H}, \mathrm{NH}), 12.53(\mathrm{~s}$, $1 \mathrm{H}, \mathrm{NH})$.

4.1.3.8. 5-[(2-Hydroxynaphthalen-1-yl)methyl]-6-(thiophen-3yl)-2-thioxo-2,3-dihydropyrimidin-4(1H)-one (6m). ${ }^{1} \mathrm{H} \quad \mathrm{NMR}$ (DMSO) $\delta 3.98\left(\mathrm{~s}, 2 \mathrm{H}, \mathrm{CH}_{2}\right.$ at $\left.\mathrm{C}-5\right), 6.98(\mathrm{~d}, 1 \mathrm{H}, \mathrm{H}$ naphthalene ring), $7.07(\mathrm{~m}, 1 \mathrm{H}, H$ thiophene ring), 7.19-7.25 (m, 2H, $H$ naphthalene ring), $7.38(\mathrm{~d}, 1 \mathrm{H}, H$ naphthalene ring), $7.55(\mathrm{~m}, 2 \mathrm{H}, H$ thiophene and naphthalene rings), $7.69(\mathrm{~m}, 1 \mathrm{H}, H$ naphthalene ring), $7.81(\mathrm{~s}$, $1 \mathrm{H}, H$ thiophene ring), $9.57(\mathrm{~s}, 1 \mathrm{H}, \mathrm{OH}), 12.28(\mathrm{~s}, 1 \mathrm{H}, \mathrm{NH}), 12.52$ (s, $1 \mathrm{H}, \mathrm{NH})$.

4.1.3.9. 5-[(2-Hydroxynaphthalen-1-yl)methyl]-6-(1-methyl1H-pyrrol-2-yl)-2-thioxo-2,3-dihydropyrimidin-4(1H)-one

(6n). ${ }^{1} \mathrm{H}$ NMR (DMSO) $\delta 3.34\left(\mathrm{~s}, 3 \mathrm{H}, \mathrm{CH}_{3}\right), 3.99$ (s, 2H, $\mathrm{CH}_{2}$ at C-5), $6.08(\mathrm{~m}, 1 \mathrm{H}, H$ pyrrole ring), $6.35(\mathrm{~m}, 1 \mathrm{H}, H$ pyrrole ring), $6.88(\mathrm{~m}$, $1 \mathrm{H}, H$ pyrrole ring), 7.01 (d, $1 \mathrm{H}, H$ naphthalene ring), 7.14-7.26 (m, $3 \mathrm{H}, H$ naphthalene ring), 7.57 (d, $1 \mathrm{H}, H$ naphthalene ring), 7.70 (d, 
$1 \mathrm{H}, H$ naphthalene ring), $9.68(\mathrm{~s}, 1 \mathrm{H}, \mathrm{OH}), 12.32(\mathrm{~s}, 1 \mathrm{H}, \mathrm{NH}), 12.59$ (s, $1 \mathrm{H}, \mathrm{NH})$.

4.1.3.10. 6-(Benzo[b]thiophen-2-yl)-5-[(2-hydroxynaphthalen1-yl)methyl]-2-thioxo-2,3-dihydropyrimidin-4(1H)-one

(6o). ${ }^{1} \mathrm{H}$ NMR (DMSO) $\delta 4.08\left(\mathrm{~s}, 2 \mathrm{H}, \mathrm{CH}_{2}\right.$ at C-5), $6.86(\mathrm{~d}, 1 \mathrm{H}, \mathrm{H}$ naphthalene ring), $7.12(\mathrm{t}, 1 \mathrm{H}, H$ naphthalene ring), $7.20(\mathrm{t}, 1 \mathrm{H}, H$ naphthalene ring), 7.37-7.39 ( $\mathrm{m}, 2 \mathrm{H}, \mathrm{H}$ benzothiophene and naphthalene rings), 7.48 (d, $1 \mathrm{H}, H$ naphthalene ring), 7.54 (s, $1 \mathrm{H}, H$ benzothiophene ring), $7.63(\mathrm{~m}, 2 \mathrm{H}, H$ benzothiophene and naphthalene rings), $7.81(\mathrm{~m}, 1 \mathrm{H}, H$ benzothiophene ring), 7.90 ( $\mathrm{m}, 1 \mathrm{H}, \mathrm{H}$ benzothiophene ring), $9.43(\mathrm{~s}, 1 \mathrm{H}, \mathrm{OH}), 12.40(\mathrm{~s}, 1 \mathrm{H}$, $\mathrm{NH}), 12.57$ (s, 1H, NH).

4.1.3.11. 5-[(2-Hydroxynaphthalen-1-yl)methyl]-6-phenethyl-2thioxo-2,3-dihydropyrimidin-4(1H)-one (6q). ${ }^{1} \mathrm{H}$ NMR (DMSO) $\delta 1.96\left(\mathrm{~m}, 2 \mathrm{H}, \mathrm{PhCH}_{2} \mathrm{CH}_{2}\right), 2.52\left(\mathrm{~m}, 2 \mathrm{H}, \mathrm{PhCH}_{2} \mathrm{CH}_{2}\right), 4.10(\mathrm{~s}, 2 \mathrm{H}$, $\mathrm{CH}_{2}$ at $\left.\mathrm{C}-5\right), 6.91(\mathrm{~m}, 2 \mathrm{H}, \mathrm{H}$ benzene and naphthalene rings), 7.13-7.28 ( $\mathrm{m}, 5 \mathrm{H}, H$ benzene and naphthalene rings), $7.38(\mathrm{~m}$, $1 \mathrm{H}, H$ naphthalene ring), $7.70(\mathrm{~d}, 1 \mathrm{H}, \mathrm{H}$ naphthalene ring), 7.78$7.83(\mathrm{~m}, 2 \mathrm{H}, \mathrm{H}$ naphthalene ring), $9.93(\mathrm{~s}, 1 \mathrm{H}, \mathrm{OH}), 12.24(\mathrm{~s}, 1 \mathrm{H}$, $\mathrm{NH}), 12.52(\mathrm{~s}, 1 \mathrm{H}, \mathrm{NH})$.

\subsection{SIRT inhibition assays}

The SIRT activity assay was performed using human recombinant SIRT1 and SIRT2 produced in Escherichia coli. The assay was performed in two stages: in the first one, that is the deacetylation phase, human SIRT1 (2 U) and the human SIRT2 ( $7 \mathrm{U}$ ), respectively, were incubated $\left(37^{\circ} \mathrm{C}\right.$ for $2 \mathrm{~h}$ ) with the substrate Fluor de LysSIRT1/2 (Biomol) in the presence of $\mathrm{NAD}^{+}$and various concentrations of tested compounds (sirtuins activators or inhibitors). As internal controls, suramin sodium, a sirtuin inhibitor, and resveratrol, a SIRT1 activator, have been included (data not shown). The second stage is initiated by the addition of the Developer II, including nicotinamide (NAM), a sirtuin inhibitor which stops the SIRT1/ 2 activity, and the fluorescent signal is produced. The fluorescence was measured on a fluorometric reader (Inphinite 200 TECAN) with excitation set at $360 \mathrm{~nm}$ and emission detection set at $460 \mathrm{~nm}$. Experiments on the SIRT1 and 2 inhibition have been performed in triplicate. $\mathrm{IC}_{50}$ data were analyzed using GraphPad Prism Software.

\subsection{Cell-cycle analysis on U937 cells}

$2.5 \times 10^{5}$ cells were collected and resuspended in $500 \mu \mathrm{L}$ of an hypotonic buffer $(0.1 \%$ Triton $\mathrm{X}-100,0.1 \%$ sodium citrate, $50 \mu \mathrm{g} /$ $\mathrm{mL}$ PI, RNAse A). Cells were incubated in the dark for $30 \mathrm{~min}$. Samples were acquired on a FACS-Calibur flow cytometer using the Cell Quest software (Becton Dickinson) and analysed with standard procedures using the Cell Quest software (Becton Dickinson) and the ModFit LT version 3 software (Verity) as previously reported. ${ }^{45}$ All experiments were completed in triplicate.

\subsection{FACS analysis of apoptosis on U937 cells}

Apoptosis was measured with the caspase 3-7 detection (BBridge) method; samples were analysed by FACS with Cell Quest technology (Becton Dickinson) as previously reported. ${ }^{46}$

\subsection{Granulocytic differentiation on U937 cells}

Granulocytic differentiation was carried out as previously described. ${ }^{46}$ U937 cells were harvested and resuspended in $10 \mu \mathrm{L}$ phycoerythrine-conjugated CD11c (CD11c-PE). Control samples were incubated with $10 \mu \mathrm{L}$ PE conjugated mouse IgG1, incubated for $30 \mathrm{~min}$ at $4{ }^{\circ} \mathrm{C}$ in the dark, washed in PBS and resuspended in $500 \mu \mathrm{L}$ PBS containing PI $(0.25 \mu \mathrm{g} / \mathrm{mL})$. Samples were analyzed by FACS with Cell Quest technology (Becton Dickinson). PI positive cells have been excluded from the analysis.

\section{Acknowledgments}

This work was supported by grants from Fondazione Roma (A.M.), Associazione Italiana per la Ricerca contro il Cancro (AIRC to L.A.), HEALTH-F4-2007-200767 'Apo-Sys' (L.A.), HEALTH-F42009-221952 'ATLAS' (L.A.).

\section{Supplementary data}

Supplementary data associated with this article can be found, in the online version, at doi:10.1016/j.bmc.2011.01.025.

\section{References and notes}

1. Denu, J. M. Curr. Opin. Chem. Biol. 2005, 9, 431

2. Michan, S.; Sinclair, D. Biochem. J. 2007, 404, 1

3. Taylor, D. M.; Maxwell, M. M.; Luthi-Carter, R.; Kazantsev, A. G. Cell Mol. Life Sci. 2008, 65, 4000

4. Milne, J. C.; Denu, J. M. Curr. Opin. Chem. Biol. 2008, 12, 11

5. Lamming, D. W.; Wood, J. G.; Sinclair, D. A. Mol. Microbiol. 2004, 53, 1003.

6. Blander, G.; Guarente, L. Annu. Rev. Biochem. 2004, 73, 417.

7. Muller, I.; Zimmermann, M.; Becker, D.; Flomer, M. Mech. Ageing Dev. 1980, 12, 47.

8. Lakowski, B.; Hekimi, S. Proc. Natl. Acad. Sci. U.S.A. 1998, 95, 13091.

9. Weindruch, R. H.; Walford, R. L.; Fligiel, S.; Guthrie, D. J. Nutr. 1986, 116, 641.

10. Roth, G. S. J. Am. Geriatr. Soc. 1999, 47, 896.

11. Pillarisetti, S. Recent Patents Cardiovasc. Drug Disc. 2008, 3, 156.

12. Lavu, S.; Boss, O.; Elliott, P. J.; Lambert, P. D. Nat. Rev. Drug Disc. 2008, 7, 841.

13. Saunders, L. R.; Verdin, E. Oncogene 2007, 26, 5489.

14. Fraga, M. F.; Agrelo, R.; Esteller, M. Ann. N.Y. Acad. Sci. 2007, 1100, 60.

15. Zhao, W.; Kruse, J. P.; Tang, Y.; Jung, S. Y.; Qin, J.; Gu, W. Nature 2008, 451, 587.

16. Outeiro, T. F.; Kontopoulos, E.; Altmann, S. M.; Kufareva, I.; Strathearn, K. E. Amore, A. M.; Volk, C. B.; Maxwell, M. M.; Rochet, J. C.; McLean, P. J.; Young, A. B.; Abagyan, R.; Feany, M. B.; Hyman, B. T.; Kazantsev, A. G. Science 2007, 317, 516.

17. Cen, Y. Biochim. Biophys. Acta 2010, 1804, 1635.

18. Biel, M.; Wascholowski, V.; Giannis, A. Angew. Chem., Int. Ed. 2005, 44, 3186.

19. Tervo, A. J.; Suuronen, T.; Kyrylenko, S.; Kuusisto, E.; Kiviranta, P. H.; Salminen, A.; Leppänen, J.; Poso, A. J. Med. Chem. 2006, 49, 7239.

20. Tervo, A. J.; Kyrylenko, S.; Niskanen, P.; Salminen, A.; Leppänen, J.; Nyrönen, T. H.; Järvinen, T.; Poso, A. J. Med. Chem. 2004, 47, 6292.

21. Trapp, J.; Jochum, A.; Meier, R.; Saunders, L.; Marshall, B.; Kunick, C.; Verdin, E.; Goekjian, P.; Sippl, W.; Jung, M. J. Med. Chem. 2006, 49, 7307.

22. Trapp, J.; Meier, R.; Hongwiset, D.; Kassack, M. U.; Sippl, W.; Jung, M. ChemMedChem 2007, 2, 1419.

23. Napper, A. D.; Hixon, J.; McDonagh, T.; Keavey, K.; Pons, J. F.; Barker, J.; Yau, W. T.; Amouzegh, P.; Flegg, A.; Hamelin, E.; Thomas, R. J.; Kates, M.; Jones, S.; Navia, M. A.; Saunders, J. O.; DiStefano, P. S.; Curtis, R. J. Med. Chem. 2005, 48, 8045.

24. Gey, C.; Kyrylenko, S.; Hennig, L.; Nguyen, L. H.; Buttner, A.; Pham, H. D.; Giannis, A. Angew. Chem., Int. Ed. 2007, 46, 5219.

25. Gutiérrez, M.; Andrianasolo, E. H.; Kyo Shin, W.; Goeger, D. E.; Yokochi, A. Schemies, J.; Jung, M.; France, D.; Cornell-Kennon, S.; Lee, E.; Gerwick, W. H. J. Org. Chem. 2009, 74, 5267.

26. Oh, W. K.; Cho, K. B.; Hien, T. T.; Kim, T. H.; Kim, H. S.; Dao, T. T.; Han, H. K.; Kwon, S. M.; Ahn, S. G.; Yoon, J. H.; Kim, T. H.; Kim, Y. G.; Kang, K. W. Mol. Pharmacol. 2010, 78, 855

27. Heltweg, B.; Gatbonton, T.; Schuler, A. D.; Posakony, J.; Li, H.; Goehle, S.; Kollipara, R.; Depinho, R. A.; Gu, Y.; Simon, J. A.; Bedalov, A. Cancer Res. 2006, $66,4368$.

28. Lain, S.; Hollick, J. J.; Campbell, J.; Staples, O. D.; Higgins, M.; Aoubala, M.; McCarthy, A.; Appleyard, V.; Murray, K. E.; Baker, L.; Thompson, A.; Mathers, J.; Holland, S. J.; Stark, M. J.; Pass, G.; Woods, J.; Lane, D. P.; Westwood, N. J. Cancer Cell 2008, 13, 454.

29. Lara, E.; Mai, A.; Calvanese, V.; Altucci, L.; Lopez-Nieva, P.; Martinez-Chantar, M. L.; Varela-Rey, M.; Rotili, D.; Nebbioso, A.; Ropero, S.; Montoya, G.; Oyarzabal, J.; Velasco, S.; Serrano, M.; Witt, M.; Villar-Garea, A.; Imhof, A.; Mato, J. M.; Esteller, M.; Fraga, M. F. Oncogene 2009, 28, 781.

30. Mai, A.; Massa, S.; Pezzi, R.; Simeoni, S.; Rotili, D.; Nebbioso, A.; Scognamiglio, A. Altucci, L.; Loidl, P.; Brosch, G. J. Med. Chem. 2005, 48, 3344.

31. Mai, A.; Rotili, D.; Tarantino, D.; Ornaghi, P.; Tosi, F.; Vicidomini, C.; Sbardella, G.; Nebbioso, A.; Miceli, M.; Altucci, L.; Filetici, P. J. Med. Chem. 2006, 49, 6897.

32. Mai, A.; Jelicic, K.; Rotili, D.; Di Noia, A.; Alfani, E.; Valente, S.; Altucci, L.; Nebbioso, A.; Massa, S.; Galanello, R.; Brosch, G.; Migliaccio, A. R.; Migliaccio, G. Mol. Pharmacol. 2007, 72, 1111. 
33. Mai, A.; Rotili, D.; Massa, S.; Brosch, G.; Simonetti, G.; Passariello, C.; Palamara, A. T. Bioorg. Med. Chem. Lett. 2007, 17, 1221.

34. Sbardella, G.; Castellano, S.; Vicidomini, C.; Rotili, D.; Nebbioso, A.; Miceli, M.; Altucci, L.; Mai, A. Bioorg. Med. Chem. Lett. 2008, 18, 2788.

35. Mai, A.; Rotili, D.; Tarantino, D.; Nebbioso, A.; Castellano, S.; Sbardella, G.; Tini, M.; Altucci, L. Bioorg. Med. Chem. Lett. 2009, 19, 1132.

36. Mai, A.; Massa, S.; Lavu, S.; Pezzi, R.; Simeoni, S.; Ragno, R.; Mariotti, F. R.; Chiani, F.; Camilloni, G.; Sinclair, D. A. J. Med. Chem. 2005, 48, 7789.

37. Mai, A.; Valente, S.; Meade, S.; Carafa, V.; Tardugno, M.; Nebbioso, A.; Galmozzi, A.; Mitro, N.; De Fabiani, E.; Altucci, L.; Kazantsev, A. J. Med. Chem. 2009, 52, 5496.

38. Pasco, M. Y.; Rotili, D.; Altucci, L.; Farina, F.; Rouleau, G. A.; Mai, A.; Néri, C. J. Med. Chem. 2010, 53, 1407.

39. Rotili, D.; Tarantino, D.; Carafa, V.; Lara, E.; Meade, S.; Botta, G.; Nebbioso, A. Schemies, J.; Jung, M.; Kazantsev, A. G.; Esteller, M.; Fraga, M. F.; Altucci, L. Mai, A. ChemMedChem 2010, 5, 674 .
40. Neugebauer, R. C.; Uchiechowska, U.; Meier, R.; Hruby, H.; Valkov, V.; Verdin, E.; Sippl, W.; Jung, M. J. Med. Chem. 2008, 51, 1203.

41. Pagans, S.; Pedal, A.; North, B. J.; Kaehlcke, K.; Marshall, B. L.; Dorr, A.; HetzerEgger, C.; Henklein, P.; Frye, R.; McBurney, M. W.; Hruby, H.; Jung, M.; Verdin E.; Ott, M. PLoS Biol. 2005, 3, e41.

42. Medda, F.; Russell, R. J.; Higgins, M.; McCarthy, A. R.; Campbell, J.; Slawin, A M.; Lane, D. P.; Lain, S.; Westwood, N. J. J. Med. Chem. 2009, 52, 2673

43. Nawrozkij, M. B.; Rotili, D.; Tarantino, D.; Botta, G.; Eremiychuk, A. S. Musmuca, I.; Ragno, R.; Samuele, A.; Zanoli, S.; Armand-Ugón, M.; ClotetCodina, I.; Novakov, I. A.; Orlinson, B. S.; Maga, G.; Esté, J. A.; Artico, M.; Mai, A J. Med. Chem. 2008, 51, 4641

44. Buu-Hoi, N. P. Saint-Ruf, G.; Loc, T. B.: Xuong N. D. J. Chem Soc. 1957, 2593.

45. Nebbioso, A.; Clarke, N.; Voltz, E.; Germain, E.; Ambrosino, C.; Bontempo, P.; Alvarez, R.; Schiavone, E. M.; Ferrara, F.; Bresciani, F.; Weisz, A.; de Lera, A. R. Gronemeyer, H.; Altucci, L. Nat. Med. 2005, 11, 77.

46. Altucci, L.; Rossin, A.; Raffelsberger, W.; Reitmair, A.; Chomienne, C.; Gronemeyer, H. Nat. Med. 2001, 7, 680. 